\title{
Characteristics and Frequency of Aphanomyces euteiches Races 1 and 2 Associated with Alfalfa in the Midwestern United States
}

\author{
D. K. Malvick and C. R. Grau, Department of Plant Pathology, University of Wisconsin-Madison, Madison 53706
}

\begin{abstract}
Malvick, D. K., and Grau, C. R. 2001. Characteristics and frequency of Aphanomyces euteiches races 1 and 2 associated with alfalfa in the midwestern United States. Plant Dis. 85:740-744.

Aphanomyces root rot of alfalfa, caused by Aphanomyces euteiches, kills seedlings and causes decline of established plants in slowly drained soils. Two races of A. euteiches that are pathogenic to alfalfa have been identified. Despite the contribution of race 1 resistance to establishment and yield of alfalfa, race 1-resistant alfalfa cultivars perform poorly in some fields infested with A. euteiches. Many isolates of A. euteiches obtained from the soils of problematic fields are of a race 2 phenotype. The purpose of this study was to determine distribution, frequency, and pathogenic and genotypic characteristics of race 1 (R1) and race 2 (R2) isolates from 21 fields: 13 in Wisconsin, 7 in Minnesota, and 1 in Kentucky. A. euteiches was successfully isolated from the soil of 16 of the 21 fields; 405 isolates were obtained from Wisconsin, 4 from Minnesota, and 48 from Kentucky. Pathogenicity and race phenotype of isolates were characterized on Saranac (susceptible to R1 and R2 isolates) and WAPH-1 (resistant to R1 and susceptible to R2 isolates) alfalfa populations. One Wisconsin field with no recent history of alfalfa production had a high frequency (51\%) of R2 isolates, and $43 \%$ of all isolates were R2 from fields with a history of alfalfa production. In a location that was planted continuously to pea for 30 years, $27 \%$ of the isolates were R2. Random amplified polymorphic DNA (RAPD) analysis of three R1 and three R2 isolates with eight primers generated 43 total polymorphic bands; however, none of the bands were uniquely associated with race phenotype. Cluster analysis based on RAPD bands revealed no consistent genotypic distinctions between R1 and R2 isolates of A. euteiches. Evaluation of eight commercial alfalfa cultivars for resistance to two R1 and two R2 isolates demonstrated that most are susceptible to R2 isolates; however, those selected for R2 resistance express resistance to R2 isolates. The results suggest that R2 isolates represent a widespread risk to alfalfa cultivars having resistance only to R1 isolates in fields with varied cropping histories.
\end{abstract}

Additional keywords: disease, DNA, Medicago, oomycete, RAPD, root rot

\begin{abstract}
Aphanomyces euteiches Drechs. causes economically important root rot diseases of several legume species when wet soil conditions prevail. This soilborne oomycete pathogen causes severe root rot damage to pea (Pisum sativum L.), alfalfa (Medicago sativa L.), snap bean (Phaseolus vulgaris L.), and red clover (Trifolium pratense L.) $(12,21,22,24,25,29)$. A. euteiches was first described as an important pathogen of pea in 1925, and was first associated with root rot of alfalfa in $1927(12,13)$. Isolates of $A$. euteiches that expressed host preference to alfalfa were first described in 1964 (24),
\end{abstract}

Corresponding author: D. K. Malvick

E-mail: dmalvick@uiuc.edu

Current address of D. K. Malvick: Department of Crop Sciences, AW-101 Turner Hall, University of Illinois at Urbana-Champaign, Urbana 61801.

Support was provided by the College of Agriculture and Life Sciences, University of WisconsinMadison as Hatch Project No. 3536.

Accepted for publication 20 March 2001.

Publication no. D-2001-0502-01R

(c) 2001 The American Phytopathological Society but it was not until the 1980s that Aphanomyces root rot was first reported to be an important and widespread disease of alfalfa $(3,8)$. Aphanomyces root rot of alfalfa has been reported in North America from Quebec, Canada and several U.S. states, including Iowa, Kentucky, New York, Virginia, and Wisconsin (1,6,19, 24,30). Disease control remains challenging in spite of the protracted awareness of this damaging disease. Chemical controls for Aphanomyces root rot are not available for legumes, and this disease is best managed by avoiding highly infested fields (7). Aphanomyces root rot is managed more successfully in alfalfa than pea because breeding for disease resistance has been much more successful for alfalfa than pea $(7,9,26,31,32)$.

Variation in host preference and virulence in populations of $A$. euteiches has likely contributed to the challenges of controlling Aphanomyces root rot. A. euteiches is composed of subspecific groups based on host of origin and host preference for pea, alfalfa, bean, pea and alfalfa, alfalfa and red clover, or none of these hosts $(6,10,15,22,29)$. The bean, alfalfa, and alfalfa and red clover groups also are geno- typically distinct based on random amplified polymorphic DNA (RAPD) analysis (15).

Variation in virulence among isolates of A. euteiches to different genotypes within a host species, also termed physiologic specialization or race, has been reported for isolates from pea and alfalfa. Most studies have focused on pea. Six pea lines were used to describe two races among 15 Michigan isolates, four races among 14 Norwegian isolates, and two races among 17 New Zealand isolates $(2,17,27)$. In another study, five isolates of A. euteiches were used to detect specific pea lines that expressed different levels of resistance within a group of pea germ plasms (16). Variation in virulence among isolates from alfalfa has been reported for isolates from several states, including Maryland, Minnesota, North Carolina, Virginia, and Wisconsin (6). Most of the isolates reported, which are now designated race 1 (R1), were highly virulent on the susceptible alfalfa cv. Saranac and expressed low virulence on WAPH-1, an alfalfa population with R1 resistance similar to resistant commercial cultivars (6). Isolates from a number of different states, however, were virulent on Saranac and WAPH-1 and are now designated race 2 (R2). It was unknown whether these $\mathrm{R} 2$ isolates represent a widespread risk to resistant commercial cultivars, which were developed using R1 isolates for screening (6).

The purpose of this study was to characterize the distribution and traits of R1 and $\mathrm{R} 2$ isolates of A. euteiches. The study was focused on Wisconsin, but limited sampling was also conducted in Minnesota and Kentucky. R2 isolates are significant because they overcome most commercially available sources of resistance to Aphanomyces root rot in alfalfa; however, only very limited information has been reported for R2 isolates $(6,20)$. Objectives were to determine the frequency and distribution of $\mathrm{R} 2$ isolates, to determine if the frequency of R2 isolates is influenced by cropping history or resistance of the baiting host, and to compare genotypic and phenotypic characteristics of R1 and R2 isolates.

\section{MATERIALS AND METHODS}

Soil sampling and isolation of $\mathrm{A}$. $\mathrm{eu}$ teiches. Fields $(n=21)$ in areas with a history of Aphanomyces root rot in Wisconsin, Minnesota, and Kentucky were sampled to determine occurrence, traits, and frequency of R1 and R2 isolates within 
fields (Table 1). Soil cores $(n=25)$ sampled to a depth of $15 \mathrm{~cm}$ were collected randomly from 4 ha in each 8- to 12 -ha field, then bulked and stored at $5^{\circ} \mathrm{C}$. $A$. euteiches was baited with seedlings of Saranac alfalfa from field soil samples placed in 140-ml waxed paper cups as described previously $(3,6)$. Sixty cups were used for each of 13 sites from Wisconsin and Kentucky (Table 1), and one isolate was obtained from an infected plant in each cup. Three cups were used for each of eight sites (7 from Minnesota and one from Wisconsin; Table 1) and one isolate was obtained from each site. Single zoospore cultures were derived from each field isolate by methods described previously and stored on corn meal agar (CMA) at $10^{\circ} \mathrm{C}(15)$.

Pathogenicity and virulence phenotype determinations. Isolates $(n=457)$ of $A$. euteiches were characterized in greenhouse trials for virulence phenotype on Saranac and WAPH-1 alfalfa populations (23). These populations were also challenged in each inoculation trial with reference isolates MF-1 (R1 isolate) and NC-1 (R2 isolate). Saranac is susceptible to all races of A. euteiches and was used to confirm pathogenicity of isolates. WAPH- 1 is resistant to $\mathrm{R} 1$ isolates and susceptible to $\mathrm{R} 2$ isolates $(5,6)$. Ten seeds of each alfalfa population were sown in 500-ml plastic containers (Dart Container Co., Mason, MI) containing vermiculite and maintained at $24^{\circ} \mathrm{C}$ prior to inoculation. Three containers were planted for each isolate by alfalfa population combination.

The effect of baiting host on the isolation of different virulence phenotypes of $A$. euteiches was determined in a separate experiment. Isolates $(n=84)$ were baited from soil samples collected at the WI-A6 site; 42 were baited with Saranac (SB) and 42 with WAPH-1 (WB) alfalfa seedlings. All 84 isolates were then inoculated individually to Saranac and WAPH-1, and disease severity on each host was determined and compared for isolates derived from SB and WB. A split plot experimental design was used, where isolates were the main plots and alfalfa populations were subplots.

Zoospores for inoculations were produced either with agar plugs from 4-dayold cultures on CMA placed into sterile deionized water, or as described by Mitchell and Yang (18). Containers containing 5-day-old seedlings were flooded, inoculated with 100 zoospores/seedling, and incubated for 4 days in a growth chamber at $24^{\circ} \mathrm{C}$ (16-h photoperiod). Then cups were reflooded for one additional day (5 days total flooding) with Hoaglands nutrient solution and incubated for 10 days at $28^{\circ} \mathrm{C}$.

Average severity index (ASI) was used as a measure of symptom severity and virulence, and was determined by scoring individual plants on a 1-to-5 scale, where 1 is an asymptomatic plant and 5 is dead $(4,9)$. The ASI value of $<3.0$ was considered a resistant reaction, and $\geq 3.0$ was considered a susceptible reaction (4). Isolates were placed into three races based on the interaction phenotypes as measured by the ASI level in inoculated plants: R0: ASI $=1$ or 2 for Saranac and WAPH-1; R1: ASI $\geq 3$ for Saranac and $<3$ for WAPH-1; and

Table 1. Sites and description of locations sampled for studies of Aphanomyces euteiches

\begin{tabular}{|c|c|c|}
\hline Sites $^{y}$ & Isolation $^{\mathrm{z}}$ & Location and field history \\
\hline WI-A1 & $\mathrm{Y}$ & Agricultural Research Station, Arlington, WI; continuous pea for 30 years \\
\hline WI-A2 & Y & Site near Janesville, WI; history of snap bean and pea production \\
\hline WI-A3 & Y & Agricultural Research Station, Hancock, WI; bean white mold nursery \\
\hline WI-A4 & $\mathrm{N}$ & $\begin{array}{l}\text { Agricultural Research Station; Hancock, WI; bean root rot nursery for } 20 \\
\text { years }\end{array}$ \\
\hline WI-A5 & $\mathrm{N}$ & Near Kaukauna, WI; no history of Aphanomyces root rot \\
\hline WI-A6 & Y & Agricultural Research Station, Lancaster, WI; long-term corn/alfalfa rotation \\
\hline WI-A7 & Y & Commercial field near Lancaster, WI Agric. Res, Station; alfalfa/corn rotation \\
\hline WI-A8 & Y & Near Loyal, WI; long-term red clover and alfalfa production \\
\hline KY-A9 & $\mathrm{Y}$ & $\begin{array}{l}\text { Soil sample from Dr. P. Vincelli; established alfalfa plots at the University of } \\
\text { Kentucky }\end{array}$ \\
\hline WI-A10 & Y & Agricultural Research Station, Marshfield WI; alfalfa root rot nursery \\
\hline WI-A11 & $\mathrm{Y}$ & $\begin{array}{l}\text { Agricultural Research Station, Marshfield WI; } 20 \text {-year plot for turf and orna- } \\
\text { mentals }\end{array}$ \\
\hline WI-A12 & $\mathrm{Y}$ & $\begin{array}{l}\text { Agricultural Research Station, Marshfield WI; field used } 20 \text { years for alfalfa } \\
\text { trials }\end{array}$ \\
\hline WI-A13 & Y & Commercial field near Denmark, WI; probable history of pea and alfalfa \\
\hline WI-B1 & Y & Baldwin, WI; commercial alfalfa field \\
\hline MN-B1 & $\mathrm{N}$ & Eyota, MN; commercial alfalfa field \\
\hline MN-B2 & $\mathrm{N}$ & St. Charles, MN; commercial alfalfa field \\
\hline MN-B3 & $\mathrm{Y}$ & Lewiston, MN; commercial alfalfa field \\
\hline MN-B4 & $\mathrm{N}$ & Altura, MN; commercial alfalfa field \\
\hline MN-B5 & $\mathrm{Y}$ & Plainview, MN; commercial alfalfa field \\
\hline MN-B6 & Y & Kasson-A, MN; commercial alfalfa field \\
\hline MN-B7 & $\mathrm{Y}$ & Kasson-B, MN; commercial alfalfa field \\
\hline
\end{tabular}

${ }^{\mathrm{y}}$ Isolates from sites designated with an A were baited with 60 cups from each site for studies of race frequency; isolates from sites designated with a B were baited with three cups from each site for studies of race occurrence.

${ }^{\mathrm{z}}$ Isolation indicates if A. euteiches was $(\mathrm{Y})$ or was not $(\mathrm{N})$ successfully isolated from these sites.
R2: ASI $\geq 3$ for Saranac and WAPH-1. Differences in symptom severity caused by isolates from each location and for isolates baited with different alfalfa populations (SB versus WB) were tested with analysis of variance, $F$ tests, and Fisher's protected least significant difference (LSD) test.

Polymerase chain reaction amplifications and RAPD assays of R1 and R2 isolates. Three $\mathrm{R} 1$ and three $\mathrm{R} 2$ isolates of A. euteiches (Table 2) were tested with RAPD analysis to determine if distinct genotypic differences exist between the two races. Aphanomyces isolates were grown and DNA was extracted as described previously (15). Eight decanucleotide primers used for this study $\left(5^{\prime}-3^{\prime}\right.$, CCTGGGCTTC, CCTGGGCTTG, CCT GCGCTTA, CCTGGGTCCA, CCTGGG CCTC, ACAGGGGTGA, CCGGCCC CAA, TTAACCCGGC) were selected based on the number of clear, reproducible, and polymorphic bands amplified from diverse set of test isolates of $A$. euteiches (15). DNA was amplified, bands were analyzed as binary data, similarity coefficients based on band sharing between isolates were calculated for all pairs of isolates, and reproducibility of bands was evaluated as described previously (15).

Reactions of select alfalfa populations to R1 and R2 isolates. Eight commercial alfalfa cultivars were evaluated in greenhouse tests for reaction to two R1 and two $\mathrm{R} 2$ isolates of $A$. euteiches (Table 2). The commercial cultivars tested were Saranac, Vernal, Pioneer 54V54, Magnum V Wet, LegenDairy YPQ, WL325HQ, DK141, and GH757, and the experimental populations tested were WAPH-1 and WAPH-5 (11). Experiments were conducted as randomized block designs with 40 plants in each of three replications. Plants were inoculated with 1,000 zoospores per plant for R1 isolates and 250 per plant for R2 isolates, scored as described above, and percent of plants expressing resistance (ASI < 3.0) was determined $(4,11)$. The experiment was conducted twice.

\section{RESULTS}

Virulence characteristics among isolates and locations. A total of 457 isolates of A. euteiches were isolated and studied:

Table 2. Race and origin of isolates of Aphanomyces euteiches used for random amplified polymorphic DNA (RAPD) analyses and/or reaction with select alfalfa cultivars

\begin{tabular}{lcc}
\hline Isolate $^{\mathbf{z}}$ & Race & Geographical origin \\
\hline MF1 & R1 & Wisconsin \\
KY10 & R1 & Kentucky \\
AOP22 & R1 & Wisconsin \\
NC1 & R2 & North Carolina \\
MPA22 & R2 & Wisconsin \\
WI98 & R2 & Wisconsin \\
\hline
\end{tabular}

${ }^{\mathrm{z}}$ All isolates were used in RAPD analysis; all except AP22 and WI98 were tested for reaction with select alfalfa cultivars. 
405 from Wisconsin, 48 from Kentucky, isolated from 16 of the 21 fields sampled, and no isolates were obtained from five fields (Table 1). Most (95\%) of the isolates were pathogenic and caused typical Aphanomyces root rot symptoms on cv. Saranac. Of the isolates studied, $64 \%$ were classified as R1, 31\% as R2, and 5\% as R0 (Table 3).

The relative frequency of races 1 and 2 and the symptom severity caused by isolates on Saranac and WAPH-1 alfalfa varand 4 from Minnesota. A. euteiches was

ied by location of origin. The WI-A2 site was dominated by R1 isolates of A. euteiches and the WI-A3 site by R2 isolates. The WI-A8 location was unique in that a higher percentage of isolates were classified as R0 and the isolates caused lower symptom severity on Saranac than did isolates from all other locations (Tables 3 and 4). For the WI-A11 site, $51 \%$ of the isolates incited ASI > 4.0 on WAPH-1, even though alfalfa had never been grown at this location. All isolates from WI-A13 were R1 and were similar to reference

Table 3. Number of isolates and frequency of isolates of Aphanomyces euteiches from 16 sites classified into three virulence groups (R0, R1, and R2) as determined on alfalfa populations Saranac and WAPH-1

\begin{tabular}{lcrcr}
\hline & & \multicolumn{3}{c}{ Frequency of isolates $(\boldsymbol{\%})^{\mathbf{y}}$} \\
\cline { 3 - 5 } Site $^{\mathbf{z}}$ & No. of isolates & $\mathbf{R 0}$ & $\mathbf{R 1}$ & $\mathbf{R 2}$ \\
\hline WI-A1 & 46 & 9 & 70 & 21 \\
WI-A2 & 51 & 0 & 96 & 4 \\
WI-A3 & 3 & 0 & 0 & 100 \\
WI-A6 & 59 & 0 & 68 & 32 \\
WI-A7 & 56 & 0 & 56 & 43 \\
WI-A8 & 36 & 0 & 64 & 14 \\
KY-A9 & 48 & 6 & 65 & 35 \\
WI-A10 & 48 & 0 & 52 & 41 \\
WI-A11 & 46 & 15 & 49 & 51 \\
WI-A12 & 0 & 62 & 23 \\
WI-A13 & 47 & 0 & 100 & 0 \\
WI-B1 & 12 & 0 & 0 & 100 \\
MN-B3 & 1 & 0 & 0 & 100 \\
MN-B5 & 1 & 0 & 0 & 100 \\
MN-B6 & 1 & 0 & 0 & 100 \\
MN-B7 & 1 & 5 & 0 & 100 \\
ALL & 1 & 64 & 31 \\
\hline
\end{tabular}

y Virulence groups: R0, ASI $=1$ or 2 on Saranac and WAPH-1; R1, ASI $\geq 3.0$ on Saranac, and $<3.0$ on WAPH-1; and R2, ASI $\geq 3.0$ on Saranac and WAPH-1.

${ }^{\mathrm{z}}$ A. euteiches was not isolated from sites WI-A4, WI-A5, MN-B1, MN-B2, or MN-B4.

Table 4. Number of isolates, average severity index (ASI), and range in ASI values for isolates of Aphanomyces euteiches from 11 sites as evaluated on alfalfa populations Saranac and WAPH- ${ }^{\mathrm{x}}$

\begin{tabular}{lclllll}
\hline & & \multicolumn{2}{c}{ Saranac } & & \multicolumn{2}{c}{ WAPH-1 } \\
\cline { 7 - 8 } \cline { 6 - 7 } Nitey & No. of isolates & ASI & Range & & ASI & Range \\
\hline WI-A1 & 46 & $3.9 \mathrm{e}$ & $1.0-4.8$ & & $2.3 \mathrm{~d}$ & $1.0-4.6$ \\
WI-A2 & 51 & $4.4 \mathrm{e}$ & $3.2-4.9$ & & $2.0 \mathrm{e}$ & $1.2-3.4$ \\
WI-A3 & 3 & $4.2 \ldots$ & $\ldots$ & & $3.1 \ldots$ & $\ldots$ \\
WI-A6 & 59 & $4.7 \mathrm{ab}$ & $3.9-5.0$ & & $2.9 \mathrm{~b}$ & $1.8-4.8$ \\
WI-A7 & 56 & $4.6 \mathrm{abc}$ & $4.1-5.0$ & & $2.7 \mathrm{c}$ & $1.8-3.6$ \\
WI-A8 & 36 & $3.2 \mathrm{i}$ & $2.1-4.6$ & & $2.5 \mathrm{~d}$ & $1.7-3.4$ \\
KY-A9 & 48 & $4.6 \mathrm{bc}$ & $3.6-5.0$ & & $2.6 \mathrm{c}$ & $1.6-3.8$ \\
WI-A10 & 48 & $4.5 \mathrm{~d}$ & $1.0-5.0$ & & $2.7 \mathrm{c}$ & $1.0-4.8$ \\
WI-A11 & 46 & $4.6 \mathrm{c}$ & $4.0-5.0$ & & $3.0 \mathrm{~b}$ & $2.0-4.0$ \\
WI-A12 & 47 & $4.2 \mathrm{f}$ & $1.3-5.0$ & & $2.4 \mathrm{~d}$ & $1.1-3.4$ \\
WI-A13 & 12 & $3.8 \mathrm{~h}$ & $3.3-4.4$ & & $2.1 \mathrm{e}$ & $1.5-2.7$ \\
WI-B1 & 1 & $4.6 \ldots$ & $\ldots$ & & $4.5 \ldots$ & $\ldots$ \\
MN-B3 & 1 & $4.8 \ldots$ & $\ldots$ & & $4.5 \ldots$ & $\ldots$ \\
MN-B5 & 1 & $4.7 \ldots$ & $\ldots$ & & $4.7 \ldots$ & $\ldots$ \\
MN-B6 & 1 & $4.5 \ldots$ & $\ldots$ & & $4.6 \ldots$ & $\ldots$ \\
MN-B7 & 1 & $4.6 \ldots$ & $\ldots$ & & $4.7 \ldots$ & $\ldots$ \\
Reference isolates ${ }^{\mathrm{z}}$ & & & & & $\ldots$ & $\ldots$ \\
MF-1 & 1 & $4.2 \mathrm{f}$ & $3.2-4.9$ & & $2.0 \mathrm{e}$ & $1.4-2.8$ \\
NC-1 & 1 & $4.7 \mathrm{a}$ & $4.0-5.0$ & & $4.5 \mathrm{a}$ & $3.8-5.0$ \\
\hline
\end{tabular}

${ }^{\mathrm{x}}$ Saranac is susceptible to R1 and R2, and WAPH-1 is susceptible only to R2 isolates. ASI = Average severity index is a measure of symptom severity based on a $1=$ healthy to $5=$ dead scale (9). Location ASI means followed by the same letter are not significantly different $(P=0.05)$ according to Fisher's protected least significant difference test; ... indicates data not included in analyses due to low number of isolates.

${ }^{y}$ Note: A. euteiches was not isolated from sites WI-A4, WI-A5, MN-B1, MN-B2, or MN-B4.

${ }^{\mathrm{z}} \mathrm{MF}-1$ and $\mathrm{NC}-1$ are $\mathrm{R} 1$ and $\mathrm{R} 2$ reference isolates, respectively. isolate MF-1, which was isolated from this site (Tables 3 and 4). Isolates from WI-A3, WI-A6, and WI-A11 sites caused the greatest symptom severity on WAPH-1, whereas the isolates from WI-A2 and WIA13 caused the lowest symptom severity on WAPH-1 and were similar to isolate MF-1 (Table 4).

Variation in symptom severity caused by groups of isolates from individual sites differed among sites of origin (Table 4). Isolates from the WI-A1, WI-A10, and WI-A12 fields incited the greatest range of symptom severity on Saranac, partly due to the relative frequencies of $\mathrm{R} 0, \mathrm{R} 1$, and $\mathrm{R} 2$ isolates (Tables 3 and 4). Isolates from the WI-A1 and WI-A10 sites incited the most variable symptom severity on WAPH-1, and isolates from the WI-A7, WI-A8, and WI-A13 locations were least variable.

Virulence phenotype of isolates baited with different hosts. Isolates baited with WAPH-1 (WB) incited significantly $(P<$ 0.05 ) higher symptom severity on WAPH1 than isolates baited with Saranac (SB) (ASI was 3.18 for SB versus 3.34 for WB; data not shown). In addition, the variance in ASI values incited by the WB isolates was 1.5 times greater on WAPH-1 than values incited by SB isolates (data not shown). The SB and WB isolates were equally virulent on Saranac. About $10 \%$ of the SB isolates and 14\% of the WB isolates incited ASI $>4.0$ on WAPH-1.

Reaction of select alfalfa populations to $\mathbf{R 1}$ and $\mathbf{R 2}$ isolates. The 10 alfalfa populations expressed distinctly different levels of resistance against two R1 and two $\mathrm{R} 2$ isolates of A. euteiches (Table 5). Cultivars with no recognized resistance to $A$. euteiches (Saranac and Vernal) were susceptible to all R1 and R2 isolates. The cultivars selected only for $\mathrm{R} 1$ resistance failed against R2 isolates. The cultivars DK141 and GH757 and population WAPH-5, which were selected for resistance to R1 and R2 isolates, expressed resistance to R1 isolates and R2 isolate NC1. Only WAPH-5 expressed resistance to R2 isolate MPA22.

Genotypic variation among isolates based on RAPD analysis. Individual RAPD primers generated from 1 to 10 amplified fragments for individual isolates (data not shown). The eight primers generated 79 total bands among the six isolates, of which 43 bands were polymorphic. None of the bands distinguished race (i.e., no bands were present in all R1 isolates and absent in all R2 isolates). Cluster analysis based on all RAPD bands revealed no distinct genotypic differences between $\mathrm{R} 1$ and R2 isolates, and all six isolates were estimated to be at least $86 \%$ similar (data not shown). Genetic similarity estimates were determined for all pairs of isolates based on the amplified fragments generated with the eight primers (Table 6). Reproducibility of RAPD analysis was demonstrated by replicate amplification of 
DNA from several isolates, resulting in the same banding pattern in all replications. Results from the RAPD analysis suggest that R1 and R2 isolates are genotypically similar based on the portion of the genome sampled with the primers used.

\section{DISCUSSION}

When Aphanomyces root rot of alfalfa was first reported to be an important disease in the midwestern United States, only one virulence phenotype (race 1) was recognized. This was due primarily to a lack of resistant alfalfa germ plasm available to distinguish races. Subsequent selection for resistance to A. euteiches in alfalfa populations led to the development of WAPH-1 and commercial cultivars with high levels of resistance to R1 isolates. When Grau et al. (6) reported isolates of $A$. euteiches that overcame the R1 resistance of WAPH-1, it was not known if these virulent isolates were common or rare, and the significance and distribution of different virulence phenotypes was largely unknown.

This study documents that R1 and R2 isolates are present in soils from diverse cropping histories and geographic locations in Wisconsin, Minnesota, and Kentucky, and reports on the variation in virulence of A. euteiches on a population level within and between individual fields. Both virulent races were recovered from soils that had not been planted to alfalfa for at least 30 years, suggesting that oospores persist in soil or that alternate hosts aid survival of A. euteiches $(24,28)$. The results suggest that R2 isolates represent a widespread risk to alfalfa cultivars having only the R1 resistance found in WAPH-1 and most commercial cultivars. This risk, however, may vary from site to site because the frequency of R1 and R2 isolates varied among fields. For example, all isolates of A. euteiches obtained from the WI-A3 site were R2 and would pose a threat to R1resistant cultivars. These studies demonstrate possible nondurability of host resistance to A. euteiches in alfalfa.

This study was designed in part to determine variation in virulence of $A$. euteiches from fields with different cropping histories. The relatively small number of fields and cropping histories included does not support prediction of the frequencies of $\mathrm{R} 1$ and R2 isolates in fields, nor do we have data to support any hypotheses aimed at factors that may influence race frequencies in fields. Results suggest that factors other than host crops in fields influence the races present. For example, the isolates recovered from alfalfa production fields did not have the highest frequency of R2 isolates, and some fields without a recent history of alfalfa production contained many R2 isolates. Our results indicate that

Table 5. Percent resistance levels for 10 different alfalfa populations against two race 1 and two race 2 isolates of Aphanomyces euteiches ${ }^{\mathrm{w}}$

\begin{tabular}{|c|c|c|c|c|c|}
\hline \multirow[b]{2}{*}{ Populations } & \multirow[b]{2}{*}{ Selection } & \multicolumn{4}{|c|}{ Resistant plants (\%) } \\
\hline & & MF1 $^{x}$ & KY10 $^{x}$ & $\operatorname{NC1}^{\mathrm{y}}$ & MPA22y $^{y}$ \\
\hline Saranac & NR & 1 & 8 & 0 & 0 \\
\hline Vernal & NR & 9 & 6 & 1 & 2 \\
\hline Pioneer 54V54 & R1 & 16 & 41 & 3 & 4 \\
\hline Magnum V Wet & $\mathrm{R} 1$ & 20 & 26 & 4 & 3 \\
\hline LegenDairy YPQ & $\mathrm{R} 1$ & 49 & 39 & 5 & 1 \\
\hline WL325HQ & $\mathrm{R} 1$ & 31 & 50 & 5 & 2 \\
\hline WAPH-1 & $\mathrm{R} 1$ & 50 & 50 & 1 & 2 \\
\hline DK141 & $\mathrm{R} 1 \& \mathrm{R} 2$ & 48 & 67 & 35 & 12 \\
\hline GH 757 & $\mathrm{R} 1 \& \mathrm{R} 2$ & 46 & 69 & 42 & 9 \\
\hline WAPH-5 & $\mathrm{R} 1 \& \mathrm{R} 2$ & 60 & 63 & 50 & 50 \\
\hline $\operatorname{LSD}(p=0.05)^{\mathrm{z}}$ & $\ldots$ & 10 & 18 & 11 & 6 \\
\hline
\end{tabular}

${ }^{\mathrm{w}}$ Percent of 40 plants expressing resistance; mean of three replications. Due to nonstandard methods used, the percent resistance values should only be considered relative to each other. Alfalfa populations were either not selected for resistance to A. euteiches (NR), or were selected for resistance to race $1(\mathrm{R} 1)$ isolates or R1 and race $2(\mathrm{R} 2)$ isolates.

${ }^{x} \mathrm{R} 1$ isolate of $A$. euteiches.

${ }^{\mathrm{y}} \mathrm{R} 2$ isolate of $A$. euteiches.

${ }^{\mathrm{z}}$ Least significant difference. host resistance may influence the frequency of R1 and R2 isolates obtained in baiting assays. The results suggest Saranac is a suitable baiting host for R1 and R2 isolates, and WAPH-1 is preferable for baiting R2 isolates. It remains unclear whether different cropping histories or alfalfa populations influence frequencies of $\mathrm{R} 1$ and R2 isolates in fields. Further, the impact of different frequencies of races on the field performance and durability of R1and R2-resistant cultivars remains poorly understood. One study (20), which compared yields of R1- versus R2-resistant alfalfa populations in a naturally infested Wisconsin field, reported that an R2resistant alfalfa population (WAPH-4) had significantly higher yields than populations susceptible to R2. Additional research is needed to determine the performance of R2-resistant cultivars in fields with and without R2 isolates under a variety of environmental conditions.

The results from this study and others $(6,14,16)$ suggest that alfalfa populations should be tested in a variety of field locations to evaluate resistance in soils with different populations and inoculum densities of A. euteiches. Breeders should consider sampling potential selection nurseries and evaluation plots to test for the presence of R1 and R2 isolates of A. euteiches. The importance of this approach is illustrated by the WI-A13 location, where no gain in R2 resistance via selection could be expected because R2 isolates of $A$. euteiches were not recovered from this location. The time and resources needed, however, to characterize virulence traits of $A$. euteiches populations in field sites can restrain the process of choosing the best selection nurseries.

RAPD analysis was used for testing genotypic differences among and between $\mathrm{R} 1$ and R2 isolates, and to determine its potential for development of a DNA-based method for characterization of virulence phenotypes. Genotypic variation among three R1 and three R2 isolates of A. euteiches was assessed using RAPD analysis, which we assume detects primarily neutral DNA markers at random coding and noncoding locations throughout the genome. All isolates differed by at least one band when all bands generated by the eight primers were considered, but there was as

Table 6. Similarity coefficients for three race 1 and three race 2 isolates of Aphanomyces euteiches based on combined data from random amplified polymorphic DNA analysis with eight primers ${ }^{\mathrm{z}}$

\begin{tabular}{|c|c|c|c|c|c|c|}
\hline \multirow[b]{2}{*}{ Isolate } & \multicolumn{6}{|c|}{ Percent similarity } \\
\hline & MF1 (R1) & KY10 (R1) & AOP22 (R1) & NC1 (R2) & WI98 (R2) & MPA22 (R2) \\
\hline MF1 (R1) & 100 & $\ldots$ & $\ldots$ & $\ldots$ & $\ldots$ & $\ldots$ \\
\hline KY10 (R1) & 69 & 100 & $\ldots$ & $\ldots$ & $\ldots$ & $\ldots$ \\
\hline AOP22 (R1) & 77 & 78 & 100 & $\ldots$ & $\ldots$ & $\ldots$ \\
\hline $\mathrm{NC} 1$ (R2) & 78 & 76 & 80 & 100 & $\ldots$ & $\ldots$ \\
\hline WI98 (R2) & 86 & 72 & 74 & 79 & 100 & $\ldots$ \\
\hline MPA22 (R2) & 90 & 72 & 78 & 82 & 82 & 100 \\
\hline
\end{tabular}

${ }^{\mathrm{z}}$ Race 1 and race 2 isolates are noted as $\mathrm{R} 1$ and $\mathrm{R} 2$, respectively. 
much genotypic variability within as between R1 and R2 isolates. Thus, there appears to be minor genotypic variability among R1 and R2 isolates, but no major genotypic differences or unique molecular markers were identified for R1 or R2 isolates with the RAPD primers and methods used. Consequently, RAPD bands were not amplified that could be used to develop specific primers for rapid characterization and diagnosis of virulence phenotypes. The primers used in this study, however, previously yielded RAPD markers that distinguished different pathotypes of A. euteiches (15). Further screening of R1 and R2 isolates with an array of additional primers will be required to determine whether RAPD analysis can be used distinguish these two races.

The results from testing commercial alfalfa cultivars and experimental populations demonstrate that selection and breeding for resistance to $\mathrm{R} 2$ isolates can result in alfalfa populations that have resistance to R2 isolates. Isolate-alfalfa population interactions were found and different isolates within a race can detect different levels of resistance. For example, the R2 resistant alfalfa entries expressed higher resistance to $\mathrm{R} 2$ isolate $\mathrm{NC}-1$ than the $\mathrm{R} 2$ isolate MPA22. Due to nonstandard methods used (4), the percent resistance values reported in this study should only be considered relative to one another.

Aphanomyces root rot of alfalfa caused by races 1 and 2 is an important, and often unrecognized, production problem in many areas. Resistance to both races may be commercially beneficial in field situations where these races and poorly drained soils occur. Breeding for resistance to different virulence phenotypes of $A$. euteiches may contribute to increased productivity of alfalfa in some areas.

\section{ACKNOWLEDGMENTS}

We thank J. Rumney for his significant contributions to this project.

\section{LITERATURE CITED}

1. Beghdadi, A., Richard, C., and Dostaler, D. 1992. Aphanomyces euteiches in alfalfa fields of Quebec: Isolation, morphology and variability of its growth and pathogenicity. Can. J. Bot. 70:1903-1911.
2. Beute, M. K., and Lockwood, J. L. 1967. Pathogenic variability in Aphanomyces euteiches. Phytopathology 57:57-60.

3. Delwiche, P. A., Grau, C. R., Holub, E. B., and Perry, J. B. 1987. Characterization of Aphanomyces euteiches isolates recovered from alfalfa in Wisconsin. Plant Dis. 71:155161.

4. Fitzpatrick, S., Brummer, J., Hudelson, B., Malvick, D., and Grau, C. 1998. Aphanomyces root rot resistance (races 1 and 2). Page D2 in: Standard Tests Bull. N. Am. Alfalfa Improvement Conf

5. Grau, C. R. 1992. Registration of WAPH-1 alfalfa germplasm with resistance to Aphanomyces root rot. Crop Sci. 32:287-288.

6. Grau, C. R., Muehlchen, A. M., Tofte, J. E., and Smith, R. R. 1991. Variability in virulence of Aphanomyces euteiches. Plant Dis. 75:1153-1156.

7. Hagedorn, D. J. 1984. Compendium of Pea Diseases. American Phytopathological Society Press. St. Paul, MN.

8. Holub, E. B., and Grau, C. R. 1990. Ability of Aphanomyces euteiches to cause disease of seedling of alfalfa compared to Phytophthora megasperma f. sp. medicaginis. Phytopathology 80:331-335.

9. Holub, E. B., and Grau, C. R. 1990. Productivity and survival of alfalfa ramets in soil naturally infested with Aphanomyces euteiches and Phytophthora megasperma. Can. J. Plant Pathol. 12:83-91.

10. Holub, E. B., Grau, C. R., and Parke, J. L. 1991. Evaluation of the forma specialis concept in Aphanomyces euteiches. Mycol. Res. 95:147-157.

11. Hudelson, B. D., and Grau, C. R. 1998. Development of a standardized test for evaluating alfalfa for resistance to Aphanomyces euteiches Race 2. Page 33 in: Rep. N. Am. Alfalfa Improvement Conf., 36th.

12. Jones, F. R., and Drechsler, C. 1925. Root rot of peas in the United States caused by Aphanomyces euteiches. J. Agric. Res 30:293325.

13. Linford, M. B. 1927. Additional hosts of Aphanomyces euteiches, the pea root rot fungus. Phytopathology 17:133-134.

14. Lockwood, J. L., and Ballard, J. C. 1959. Factors affecting a seedling test for evaluating resistance of pea to Aphanomyces root rot. Phytopathology 17:133-134.

15. Malvick, D. M, Grau, C. R., and Percich, J. A. 1998. Characterization of Aphanomyces euteiches strains based on pathogenicity tests and random amplified polymorphic DNA analyses. Mycol. Res. 102:465-475.

16. Malvick. D. K., and Percich, J. A. 1999. Identification of Pisum sativum germplasm with resistance to root rot caused by multiple strains of Aphanomyces euteiches. Plant Dis. 83:51-54.

17. Manning, M. A., and Menzies, S. A. 1984.
Pathogenic variability in isolates of Aphanomyces euteiches from New Zealand soils. N Z. J. Agric. Res. 27:569-574,

18. Mitchell, J. E., and Yang, C. Y. 1966. Factors affecting growth and development of Aphanomyces euteiches. Phytopathology 56:917-922.

19. Munkvold, G. P., and Carlton, W. M. 1995. Prevalence and distribution of Aphanomyces euteiches and Phytophthora medicaginis in Iowa farm fields. Plant Dis. 79:1251-1253.

20. Munkvold, G. P., Carlton, W. M., Brummer, E. C., Meyer, J. R., Undersander, D. J., and Grau, C. R. Virulence of Aphanomyces euteiches isolates from Iowa and Wisconsin and benefits of resistance to A. euteiches in alfalfa cultivars. Plant Dis. 85:328-333.

21. Papavizas, G. C., and Ayers, W. A. 1974 Aphanomyces species and their root diseases in pea and sugarbeet. U.S. Dep. Agric. Agric. Res. Serv. Bull. No. 1485.

22. Pfender, W. F., and Hagedorn, D. J. 1982 Aphanomyces euteiches $\mathrm{f}$. sp. phaseoli, a casual agent of bean root and hypocotyl rot. Phytopathology 72:306-310.

23. Rumney, J. S. 1994. Studies of the interaction of Aphanomyces euteiches and Medicago sativa: evidence of host genetic vulnerability. Ph.D. Thesis. University of WisconsinMadison.

24. Schmitthenner, A. F. 1964. Prevalence and virulence of Phytophthora, Aphanomyces, Pythium, Rhizoctonia, and Fusarium isolated from diseased alfalfa seedlings. Phytopathology 54:1012-1018.

25. Sherwood, R. T., and Hagedorn, D. J. 1962. Studies on the biology of Aphanomyces euteiches. Phytopathology 52:150-154.

26. Stuteville, D. L., and Erwin, D. C., eds. 1990. Compendium of Alfalfa Diseases. 2nd ed. American Phytopathological Society Press. St. Paul, MN.

27. Sundheim, L. 1972. Physiologic specialization in Aphanomyces euteiches. Physiol. Plant Pathol. 2:301-306.

28. Temp, M. V., and Hagedorn, D. J. 1962. Influence of cropping practices on Aphanomyces root rot potential of Wisconsin pea fields. Phytopathology 57:667-670.

29. Tofte, J. E., Smith, R. R., and Grau, C. R. 1992. Reaction of red clover to Aphanomyces euteiches. Plant Dis. 76:39-42.

30. Vincelli, P. C. 1992. Potential for seedling disease of alfalfa caused by Aphanomyces euteiches in a Kentucky soil. Plant Dis. 76:622626.

31. Vincelli, P., Lauriault, L. M., and Henning, J. C. 1995. Yields of alfalfa selected for Aphanomyces resistance in Kentucky. Agron. J. 87:748-752.

32. Wiersma, D. W., Grau, C. R., and Undersander, D. J. 1994. Phytophthora and Aphanomyces root rot resistance means higher alfalfa yields in Wisconsin. J. Prod. Agric. 8:259-264. 